\title{
Medicolegal evaluation of a maternal filicide attempt: a case report
}

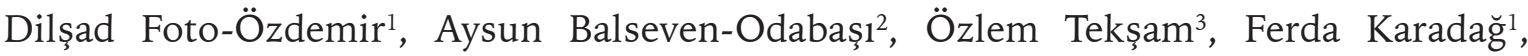 \\ Ramazan Akçan², Eda Yılmaz ${ }^{4}$ \\ Departments of ${ }^{1}$ Child and Adolescent Psychiatry, ${ }^{2}$ Forensic Medicine, ${ }^{3}$ Pediatrics, Hacettepe University Faculty of \\ Medicine, Ankara; ${ }^{4}$ Department of Forensic Medicine, Erzurum Education and Research Hospital, Erzurum, Turkey. \\ E-mail:dilsad_ozdemir@yahoo.com ordilsad.fotoozdemir@hacettepe.edu.tr \\ Received: 14th May 2019, Accepted: 17th October 2019
}

\begin{abstract}
SUMMARY: Foto-Özdemir D, Balseven-Odabaşı A, Tekşam Ö, Karadağ F, Akçan F, Yılmaz E. Medicolegal evaluation of a maternal filicide attempt: a case report. Turk J Pediatr 2019; 61: 622-628.

Filicide mainly refers to the murder of a child by his/her parents. Even though filicide is a rare event, outcome of filicide is more severe compared to other types of murders. In this report, we aim to discuss the factors in which the case of a woman who attempted to kill her 2.5-year-old daughter along with the demographical characteristics. Twenty-nine-year-old mother attempted to kill her daughter by hanging. Even though the victim did not die as the mother, regretted her action the triggers and the plot of the case discussed within the filicide framework. Therefore, the presented case report would contribute to the understanding of the nature of the filicide, and it might bring a different perspective, because of the different development process of filicide, sharing the disorder and interwoven motivations between the child and mother. In this respect, we aim to draw attention of pediatricians, child psychiatrists and forensic pathologists about the importance of filicide.
\end{abstract}

Key words: filicide, maternal filicide, fatal child abuse.

The killing of a child by a parent is known as filicide. ${ }^{1}$ Even though filicide is a rare act, its consequences are much more severe compared to other types of murders. ${ }^{2}$ Neonaticide mostly refers to the murder of 24 hours old and younger babies while infanticide is used for the murder of 12 months old and younger babies. ${ }^{3}$ The murder of children above 12 months is named as filicide. The notion of 'General Filicide' covers all three categories. ${ }^{4}$ The victims and perpetrator of filicide might show various characteristics. ${ }^{3}$ Children are generally under higher risk during the first day of their lives. ${ }^{2}$ Filicide is commonly considered as a female crime; however, paternal filicide cases have recently been reported especially in the Western countries. ${ }^{1}$ Mother abusers are more common during the neonatal period while father or stepfather also take part in filicide cases, in the later stages. ${ }^{3}$ Fathers generally use active filicide methods such as stabbing, while mothers use passive methods such as whelming and exposure to poisonous gases. ${ }^{5}$ Due to physical and cultural differences, filicide cases show different demographic characteristics and different patterns of killing. ${ }^{2}$ In order to tackle risk factors of filicide, it is crucial to conduct social evaluation of the families, to provide support for the families carrying risk factors such as socio-economic troubles and domestic conflicts and to provide treatment for the psychiatric diseases of family members. Understanding family dynamics and parental characteristics are important for recognizing the families under risk and carrying out necessary interventions. Detailed and rigorous evaluation are required for the cases directed with filicide suspicion. It is important that the evaluation of other family members by multidisciplinary teams interpret the risk factors and triggers of filicide act from a comprehensive and holistic perspective. The 
aim of this report is to discuss the characteristics of a case who was hung on the wall of her home by her mother. In this way, the study aims to draw the attention of pediatricians, child psychiatrists, psychologists, social workers and forensic pathologists who often face with child victims to the importance of filicide.

\section{Case Report}

Two years-old girl M., who was known to have no previous history of illnesses, was admitted to the Pediatric Emergency Department with an account of hanging. The history of the case revealed that her mother had hanged $\mathrm{M}$. with a 2 meter-long rope on the wall. After two minutes of hanging, the mother asked for help from neighbors and M., was saved from the position. M., cried after the incident, she did not become cyanotic, but she had seizures lasting 10-15 seconds, twice. A circular hypodermic lesion on the victim's neck was observed in the emergency department. She suffered from confusion and Glasgow Coma Scale Score was 6-7. Tonic-clonic convulsions lasting 1015 seconds, remitted with diazepam, were observed. Brain edema or cervical fracture was not observe on cranial and cervical Computed Tomography. Treatment with 3\% $\mathrm{NaCl}(4 \mathrm{cc} / \mathrm{kg})]$ was started to preventing brain edema. After seven day of follow-up and full physical recovery, the patient was taken under protection and placed in social service facility. Before she was taken under protection, psychiatric interviews with the victim's family members were performed in order to evaluate the case and family dynamics.

\section{Psychiatric Assessment and Clinical Process} Interview with family members revealed that $M$. was the second child from the second pregnancy of the 29 years old mother. The examination of 2.5 years old $M$. by the Department of Child and Adolescent Psychiatry showed that her developmental stages were age-appropriate and she seemed nervous and having difficulties to leave her grandmother.

Psychiatric assessment of the family: It was stated that her parents 12-year-old marriage was consensual and both parents were in love. It was also mentioned that the parents earned their living by selling things in local bazaars and they lived in a house belonging to their grandmother. It was revealed that grandparents were not satisfied with M.'s parents' marriage at the beginning; but later they did not have serious problems with M.'s mother. However, some domestic conflicts seemed to exist between them. During the interviews, it was noticed that the father was talking and behaving inconsistently and both families were blaming each other. There were severe conflicts between the father's and mother's families. It was considered that the father and his parents might be defensive, had difficulties about explaining the details of the incident and tried to demonstrate that the marriage was better than it actually was. Due to the inconsistent expressions of the two families, it was decided to conduct an interview with M.'s sister's teacher. According to the information received from the teacher, the father worked illegally and there were severe conflicts between the father and the mother. It was stated that M.'s parents had problems in their marriage for a long period. Three months before the presented incident, the mother left home with children and stayed with her mother for one month. M.'s father threatened the mother with a knife saying he would hurt both himself and her if she would not return home. Then, she planned to leave her children and husband. However, she returned home giving him a second chance due to the insistence of the relatives. The problems continued after the mother returned home.

The father: The father's relationship with children was cold and distant. It was observed that he had behavioral problems, he was angry most of the time and was negligent about his home and children. He was generally quite defensive. It was learned that the father was a drug abuser, he had been generally abusing heroin. He also dealt drugs, he was in trouble with many people and he had a complicated and chaotic life. For this reason the parents had serious problems with their marriage. During the interviews, the father stated that it was impossible for his wife to hurt her children, his wife was dedicated to her children and they had a happy family life and did not have any problems in their marriage. He accused other family members about the incident. He was suspicious of his brother and 
other family members. It was noticed that the father's expressions were inconsistent and the information he gave was inaccurate.

The mother: The mother was 29 years old. She was born to a low-income family. Her family did not approve of the marriage. She became pregnant immediately after her marriage and had two daughters 8 and 2.5 years old (our case). Her relationship with her family, friends and neighbors was restricted by her husband. It was learned that she was involved with her children, especially with M. However, she had been depressed recently due to the problems in her marriage that and that her parenting skills were declining. It was revealed that she took decisions to leave home and her children. Accurate information about the day of the incident and the way the incident happened could not been received due to the inconsistent statements and chaotic structure of the involving families. All family members agreed that the mother could not do such a thing since she loved her children so much. Even if she did such a thing, she could not be in her senses. It was learned that she was with her daughter before the incident happened and there were not any abnormalities in her behaviors. The mother was described to be shocked that she could still not remember how the incident happened. It was stated that the mother did not talk much. She did not have a previous diagnosis for a psychological disorder and had not seen a specialist concerning her recent mental distress. She had a history of conversion disorder in the form of convulsive symptoms before marriage. During the marriage, she continued to have convulsive symptoms and she had been depressed, unwell and introverted, before the incident. It was determined from the police statement that she was having problems with her husband, her husband was a drug abuser, she wanted to divorce but her husband but he threatened her by not showing the children to her. She thought that the father would not able to look after the children so she tried to kill the victim, then she regretted her action and wanted help from her neighbors.

The Children: The evaluation of M., showed that her developmental stages were age- appropriate and she seemed nervous and having difficulties to leave her grandmother. Her sister also had normal developmental characteristics appropriate with her age. It was learned that her sister was playing outside during the incident and she learned about the incident from her friends. The sister was nervous, she was afraid of being hurt such so that she could not go to school and she stayed with the mother's family. The sister mentioned that her uncle visited them occasionally and had fights with the father so he might have hanged her sister. The sister's Beier Sentence Completion Test results showed that the repetitive sentences were mostly about the love and tolerance of her mother towards her children. The sister stated that she could not understand why her mother was arrested. She expressed that she would save her mother and the victim if she could. During the evaluations, the father's family was considered suitable for the further care of the children. However, it was noticed that the grandmother was not willing to look after the children since she stated that she was sick, she had to work and she had so much to do. Due to mutual accusatory behaviors of the families, there was doubt concerning the victim's safety after her recovery if she was returned to her family. For this reason, the victim and her sister were placed in a social service house after social evaluations. During follow-up, one month after M. was placed in social service house, she was observed in a shy mood. She stayed in the social worker's arms during the interview and she acted insecure in a new environment. It was determined that she had been disinterested towards her environment in the house and did not speak to anyone. It was noted that she had recently become more active but she was still a composed child. After psychiatric evaluation, M. was considered to be suffering from depressive symptoms and separation anxiety. She needed a regular psychiatric follow-up and play therapy. Psychiatric follow up in frequent intervals was planned for the victim. Informed consent was taken from father for publication.

\section{Discussion}

Maternal filicide is the murder of child by his/her own mother. In this study, we aim 
to determine the risk factors that provide the ground for filicide act, review preventive measures and raise awareness about filicide among the experts who work with children. In this case, the low socio-economic status of mother, problems between parents, lack of education and social support, the loss of parenting skills under stress, using dysfunctional coping skills and the feeling of hopelessness are considered as the factors behind the filicide attempt. The studies so far categorized filicide cases according to the trigger of death and cause of murder. ${ }^{2}$ Resnick divided the category of murder of child above 24 hours-old. Since cases presented by Resnick et $\mathrm{al}^{2}$ had not reflected the population, there was a need for new classifications. D'Orban ${ }^{6}$ divided filicide into six different categories: 1 . Beater-abuser mother; 2. Mother with mental illness; psychotic disorders or suicide related depression; 3 . Neonaticide; 4 . The revengeful mother; 5. The unwanted child; 6. Altruistic filicide. While boys are under greater risk in revenge cases, altruistic mothers often choose to kill their girls. ${ }^{3}$

When we look at the characteristics of the families with filicide history and the risk factors mentioned in the literature, being under intensive stress and lacking supportive factors increase the risk of filicide act. The difficulties about looking after the child; social isolation; financial problems; sexual abuse history; problems with family members and about marriage; alcohol or drug dependence also can be reasons of filicide. In accordance with the literature, the mother in our case study was economically dependent, had insufficient support for childcare, had low education level and socio-economic status and had insufficient social support. In our case, M.'s parents had been having severe conflicts and the family environment was significantly chaotic. The father was unemployed, addicted to drugs and was working illegally. Besides, the father was anti-social and negligent towards his home and children. He was trying to keep his wife under his control through emotional and physical pressure. He threatened his wife by hurting himself and her when she left home. He also threatened her by not showing her children in case she left home permanently. The mother was in a hopeless condition. She was considered to attempt filicide with her protective maternal instincts since she thought that the father was not eligible to look after her children. When we look at the reasons of murder attempt, the case can be classified under D'Orban ${ }^{5}$ altruistic filicide category. The literature strongly emphasizes the psychopathologies of the mothers (often diagnosed with depression and psychotic disorders) involved in filicide. The higher possibility for women to develop a mental disorder during the first year of motherhood was mentioned. ${ }^{7-9}$ Stress, social problems and mental disorders are considered as triggers of filicide. However, these factors are also common for the population of mothers who do not attempt filicide. ${ }^{2}$ Hence, these factors are limited for explaining the act of filicide. Depression and psychotic disorders are common among the mothers who commit filicide. ${ }^{10}$ However, maternal psychiatric disorders were not noted in the presented case. On the other hand, the mother was trying to maintain a challenging marriage and had depressive symptoms. She also had conversion symptoms that started before the marriage and continued afterwards. After the incident, she started to show dissociative symptoms, as well. Overall, her traumatic life had reduced the her coping strategies and led her to feel disappointment, low selfrespect and hopelessness. In the literature, it is stated that long-term disappointments and instabilities can be catalyzers of filicide. ${ }^{11}$ Due to their suicidal thoughts, they aim to protect their children by killing them. ${ }^{12}$ It is common for the depressive mothers to plan filicide and suicide at the same time. For this reason, suicidal thoughts might be an important trigger of filicide. Studies regarding filicide from psychodynamic perspective underline the theories of attachment, object relations and separation-individuation. Willemse ${ }^{13}$ argues that the parents with filicide history have emotional dysregulation and borderline personality. Emotional regulation provides the abilities for expressing feelings, controlling violence and editing emotional impulses. Individuals naturally learn emotional regulation through the relations between the caregiver and caretaker. Over-loving or over-identification 
and problems about separation makes the mother unable to distinguish herself from her child. From a developmental perspective, a normal separation-individualization process of a child is possible when this child is ready to operate independently. For this reason, separation of the child from this symbiotic bond is necessary. Enabling the physical separation and autonomous functioning of a child helps in establishing a sense of being separate from the caregiver. However, devoted herself, overly intrusive, and inseparable mother, like in our case, interrupts the natural course of development of separationindividualization. The mother conceives her children as an extension of her body and she performs filicide in order to damage herself. ${ }^{13,14}$ When the mother cannot tolerate the inner pain and fear, she might transform her inner conflict to physical violence towards her children and attempt filicide. ${ }^{14}$ In contrast, the lack of bonding and attachment are commonly claimed as important risk factors for filicide. Spinelli ${ }^{12}$ refers to ego, denial, dissociation and depersonalization to explain filicide. His study with mothers who kill their child shows that $80 \%$ of the mothers had dissociative experiences. ${ }^{15}$ In our case, early childhood experience and the mother's coping skills could not be evaluated. However, based on the evaluations of the family members, she was a devoted mother who had a strong relationship with her children. Her strong feelings towards $\mathrm{M}$. and the connection pattern which didn't allow the healthy separation-individuation might have led her see $M$. as an extension of her body. When she could not tolerate the pain and fear rising from loneliness, long term frustration, instability and deadlocked marriage, she might have transformed her inner conflict to violence against her child as an extension of her body. Some individuals express their intensive anger and hate based on traumatic events through aggressive behavior. In contrast, the intensive feelings of anger and hate turn to an attempt towards self-destruction in some people. Considering filicide and suicide as telescopic cases, filicide can be conceptualized as a suicidal act by the mother who cannot differentiate herself from her child. At the same time, the mother directs her intense devastating offensive feelings towards another person by performing filicide. The dissociation after severe traumatic experience was also noted in the M.'s mother. She could not remember and explain the details of the incident. She described in a fearful, confused and pointless mood after the incident which are indications of maternal dissociative amnesia. Dissociative experiences may cause amnesia and confused perception of time, people and place. Inability to feel the pain may also been observed after dissociative experiences. In our case, the mother used to be devoted, but recently increasing emotional stress negatively affected her mothering skills. She started having difficulties taking care of her children and she had plans about leaving her family. It is considered that the mother had negative feelings about not meeting the expectations of being 'a good mother' which in turn resulted in low self-respect. Overall, these factors are regarded as the triggers of her filicide act. ${ }^{12}$

Another important factor for the act of filicide is the age of the victim. Younger children are under greater risk of being the victims of filicide. In addition, neurologic, genetic, metabolic disorders and delay of mental and physical development may also increase the risk for the child to be victim of filicide act. ${ }^{10}$ In our case, the mother chose the younger one among the two children. The psychiatric evaluation revealed that the mother was especially involved with her second child. At first, she left home but, it was considered that she was concerned about not being able to see her children again. She also thought that the father was incapable of taking care of the children. For this reason, the mother might have attempted filicide in order to protect her second child, because she was more vulnerable and defenseless according to her idea.

Although filicide may cause anger and pain in the population, most of the time the performer is also a victim. It is common for the mothers who perform filicide to have the history of physical, sexual or emotional abuse in their past. ${ }^{5}$ It is stated that $90 \%$ of the mothers who kill their child have early childhood trauma and are subjected to emotional abuse, physical violence, rejection and negligence. These stress 
factors may cause defects in the development of ego and superego. ${ }^{12}$ In our case, the mother seemed to be unattended and deprived from social support, so she found the solution for her problems in leaving her children. It is not wrong to say that she was a young woman who had been severely emotionally abused by her husband who threatened her by murder. She was also subjected to severe negligence both by her family and her husband. Due to reluctant behaviors of the families about taking care of the children and the chaotic and unreliable family structures, the children were taken under protection by social service house. This also indicates that the mother was in a negligent and abusive environment.

Since risk factors of filicide are common among society, there are problems about its prevention. Comprehensive studies on larger case number are needed in order to determine the population with filicide risk. ${ }^{16}$ The history of crib death and the suspicion of filicide increase the family's need for support. A multidisciplinary approach by family physicians, pediatricians, social service experts and psychiatrics is essential for supporting families and preventing the possible filicide cases in risky families. ${ }^{2,10}$ Healthcare workers and social service experts should evaluate the risky pregnant women and mothers to prevent filicide. ${ }^{17}$ Children under risk should be evaluated to prevent maternal filicide and proper socio-cultural support should be provided to the mothers. ${ }^{10}$ The families should be informed about filicide. ${ }^{10,17}$ Increasing awareness among the pediatricians who often work with filicide victims; social evaluation of the families and developing possible solutions to socio-economic problems; treating maternal psychiatric disorders such as depression and psychosis can be significant for reducing risk factors and preventing possible filicide acts. ${ }^{17}$

\section{Acknowledgements}

We are grateful to head of Hacettepe İhsan Doğramacı Children's Hospital and the members of Hospital's Child Protection Team (Kadriye Yurdakök, Elif Özmert, Orhan Derman, Nuray Kanbur, S.Songül Yalçın, Ali Rıza Tumer, Ş. Gülin Evinç, Sinem Akgül, and
Helin Atik) for their assistance and support in management of the case.

\section{REFERENCES}

1. Liem M, Koenraadt F. Filicide: A comparative study of maternal versus paternal child homicide. Crim Behav Ment Health 2008; 18: 166-176.

2. Stanton J, Simpson A. Filicide: A review. Int J Law Psychiatry 2002; 25: 1-14.

3. Bourget D, Grace J, Whitehurst L. A review of maternal and paternal filicide. J Am Acad Psychiatry Law Online 2006; 35: 74-82.

4. Krischer MK, Stone MH, Sevecke K, Steinmeyer EM. Motives for maternal filicide: Results from a study with female forensic patients. Int J Law Psychiatry 2007; 30: 191-200.

5. D'Orban PT. Women who kill their children. Br J Psychiatry 1979; 134: 560-571.

6. Mugavin ME. A meta-synthesis of filicide classification systems: Psychosocial and psychodynamic issues in women who kill their children. J Forensic Nurs 2005; 1: 65-72.

7. Eke SM, Basoglu S, Bakar B, Oral G. Maternal filicide in Turkey. J Forensic Sci 2015; 60 (Suppl 1): S143-S151.

8. Valença AM, Mendlowicz MV, Nascimento I, Nardi AE. Filicide, attempted filicide, and psychotic disorders. J Forensic Sci 2011; 56: 551-554.

9. Lambie ID. Mothers who kill: The crime of infanticide. Int J Law Psychiatry 2001; 24: 71-80.

10. Friedman SH, Resnick PJ. Child murder by mothers: Patterns and prevention. World Psychiatry 2007; 6: 137-141.

11. Scott P. Parents who kill their children. Med Sci Law 1973; 13: 120-126.

12. Jackson D. A Meta-Study of Filicide: Reconceptualizing Child Deaths by Parents: Arizona State University, 2011.

13. Willemsen J, Declercq F, Markey S, Verhaeghe P. The role of affect regulation in a case of attempted maternal filicide-suicide. Clin Soc Work J 2007; 35: 215-221.

14. Kunst JL. Fraught with the utmost danger: The object relations of mothers who kill their children. Bull Menninger Clin 2002; 66: 19-38.

15. Spinelli MG. A systematic investigation of 16 cases of neonaticide. Am J Psychiatry 2001; 158: 811-813. 
16. Lewis CF, Bunce SC. Filicidal mothers and the impact of psychosis on maternal filicide. J Am Acad Psychiatry Law Online 2003; 31: 459-470.
17. Balseven Odabaşı A, Neonatasid, İnfantisid ve Filisid; Temel Pediatri İçinde: E. Hasanoğlu E, Düşünsel R (ed). Ankara: Güneş Tıp Kitapevleri, 2010, Bölüm XXXI, 1737-1739. 